\title{
EVALUASI KINERJA MENGAJAR GURU IPS DALAM MENGIMPLEMENTASIKAN TPACK
}

\author{
Joni Ruta Pulungtana ${ }^{1}$, Yari Dwikurnaningsih ${ }^{2}$ \\ 1,2 Program Pascasarjana Magister Manajemen Pendidikan \\ FKIP Universitas Kristen Satya Wacana, Indonesia \\ e-mail: umbujhonny@gmail.com ${ }^{1}$, Yari.dwikurnaningsih@uksw.edu²
}

\begin{abstract}
Abstrak
Tujuan penelitian ini adalah untuk mengevaluasi kinerja mengajar guru IPS dalam mengimplementasikan TPACK, dari aspek perencanaan, pelaksanaan, dan evaluasi pembelajaran di SMA Kristen Satya wacana. Jenis penelitian ini adalah penelitian evaluatif, dengan subyek penelitian Guru-guru yang tergabung dalam kelompok peminatan IImu Pengetahuan Sosial dengan jumlah 7 orang Guru. Teknik pengumpulan data menggunakan observasi, studi dokumen, kuesioner dan wawancara. Teknik analisis data kualitatif dilakukan dengan pengumpulan data, reduksi data, penyajian data, dan kesimpulan sedangkan data kuantitatif dianalisis secara deskriptif sederhana dengan menghitung rerata, persentase dan dikategorikan. Hasil penelitian dari aspek perencanaan pembelajaran, secara keseluruhan berada pada kategori baik dengan persentase sebesar $84.66 \%$. Dari aspek pelaksanaan pembelajaran, secara keseluruhan berada pada kategori baik dengan persentase sebesar $81.25 \%$. Dari aspek Evaluasi pembelajaran, secara keseluruhan berada pada kategori baik dengan persentase sebesar 85.78.
\end{abstract}

Kata kunci : Evaluasi, Kinerja Mengajar Guru, TPACK

\section{Abstract}

The purpose of this study was to evaluate the teaching performance of social studies teachers in implementing TPACK, from the aspects of planning, implementation, and evaluation of learning in Satya Wacana Christian High School. This type of research is an evaluative study, with research subjects Teachers who are members of the Social Sciences specialization group with a total of 7 teachers. Data collection techniques using observation, study documents, questionnaires, and interviews. Qualitative data analysis techniques are performed by data collection, data reduction, data presentation, and conclusions. The quantitative data are analyzed in a simple descriptive manner by calculating the mean, percentage and categorized. The results of this research are from aspect of lesson planning, overall are in the good category with a percentage of $84.66 \%$. From the aspect of the implementation of learning overall is in the good category with a percentage of $81.25 \%$. From the aspect of learning evaluation overall is in the good category with a percentage of $85.78 \%$.

Keywords : Evaluation, Performance of Teaching Teachers, TPACK 


\section{PENDAHULUAN}

Abad 21 adalah abad teknologi dan informasi, pengetahuan, digital, yang merupakan suatu masa dengan tuntutan yang lebih rumit, menantang serta memiliki spesifikasi tertentu yang ternyata sangat berpengaruh terhadap kehidupan manusia. Perkembangan teknologi dan informasi yang sangat cepat dalam berbagai aspek kehidupan termasuk dalam bidang pendidikan lebih khusunya dalam pembelajaran telah diintervensi oleh keberadaan teknologi ini (Daryanto dan karim 2016:7). Perkembangan yang demikian cepat harus diiringi oleh pelaksanaan pendidikan yang signifikan dengan dengan tuntutan perubahan tersebut.

Sejalan dengan hal tersebut, era transformasi abad ke-21 merupakan arus perubahan dimana guru dan siswa akan samasama memainkan peranan penting dalam kegiatan pembelajaran. Terkait dengan pembelajaran berdasarkan Kurikulum 2013, dalam Permendikbud nomor 22 tahun 2016 tentang Standar Proses pendidkan Dasar dan Menengah dijelaskan bahwa beberapa prinsip pembelajaran dalam Kurikulum 2013 yang relevan dengan perkembangan zaman dan salah satunya yaitu pemanfaatan teknologi informasi dan komunikasi untuk meningkatkan efisiensi dan efektivitas pembelajaran. Terkait hal itu, yang dikembangkan dalam standar proses mencakup tiga bagian yaitu, Perencanaan Pembelajaran, Pelaksanaan Pembelajaran, dan Penilaian atau evaluasi hasil belajar.

Salah satu faktor mendasar yang menentukan tercapainya tujuan pedidikan adalah guru (Wirawan 2015:3). Peranan guru amat sangat signifikan bagi setiap keberhasilan proses pembelajaran dan kemampuan guru merupakan variabel terpenting dalam pendidikan. Namun demikian kemampuan guru untuk meningkatkan mutu pendidikan sangat dipengaruhi oleh kemampuan profesional guru serta kinerjanya (Muhsin \& Sutomo 2016: 4). Menyadari peran guru sangat penting sehingga pemerintah menetapkan guru sebagai tenaga profesional, guru harus mempunyai kualifikasi akademik, sertifkat pendidikan, dan kompetensi yang sesuai dengan bidangnya. Ada empat kompetensi yang harus dimiliki guru yaitu kompetensi kepribadian, kompetensi sosial, kompetensi pedagodik dan kompetensi profesional (UU No. 14 Tahun 2005 tentang guru dan dosen).

Berdasarkan Permendiknas tahun 2007 dapat dilihat bahwa kompetensi kepribadian dan kompetensi sosial lebih berkaitan dengan kemampuan guru menyesuaikan diri dengan lingkungan intra maupun ekstra sekolah, sedangkan kompetensi pedagodik dan kompetensi profesional guru lebih mengarah pada profesionalismenya sebagai seorang guru, sebagai tenaga yang profesional dimana guru dituntut untuk mampu mengintegrasikan teknologi dalam proses pembelajaran. Standar proses dalam kurikulum 2013 dengan pendekatan saintifik menyebutkan bahwa prinsip pembelajaran yang digunakan harus memanfaatkan teknologi informasi dan komunikasi untuk meningkatkan efisiensi dan efektivitas pembelajaran (Permendikbud, 2016:2). Marzano \& Heflebower (2012:34) dalam bukunya yang berjudul "Teaching \& Assessing 21st Century Skills" menjelaskan bahwa ada tiga aspek atau bidang yang harus dimiliki oleh seorang guru, yaitu: 1) Keterampilan pembelajaran dan inovasi, 2) Keterampilan informasi, media dan teknologi, 3) Kecakapan hidup dan karier. Tentunya, hal tersebut harus dimulai dari sisi guru sebagai fasilitator pembelajaran. Ketrampilan tersebut disebut sebagai bagian dari pembelajaran abad 21.

Pengetahuan Guru dalam mengintegrasikan teknologi dalam mengajar dan menguasai konten dikenal dengan istilah Techonological pedagogical, content knowledge (TPACK). Secara garis besar didalam TPACK mengambarkan tentang tiga komponen utama yaitu: pedagogik, konten, teknologi, yang dapat dijadikan sebagai dasar dalam mengembangkan diri dan inovasi pembelajaran (Suyawati dkk, 2014:68). Ibnu dan Nurita (2018: 49) mengatakan bahwa dengan adanya TPACK, dapat membantu guru dalam memfasilitasi siswa untuk memahami sutau konten pembelajaran terutama dalam hal materi yang bersifat abstrak dan tentunya perlu dipertimbangkan aspek pedagogis. Dengan memiliki kompetensi TPACK yang memadai akan sangat membantu bagi seorang guru dalam melakukan aktivitas pembelajaran, karena prosesnya lebih kompleks, situasional, dan dinamis, sehingga akan menciptakan suasana pembelajaran yang menyenangkan, aktif, kreatif, dan inovatif.

Berdasarkan studi pendahuluan di SMA Kristen Satya Wacana sangat memungkin untuk menerapkan TPACK dalam proses pembelajaran. Hal ini didukung dengan berbagai kondisi yang ideal dalam 
menerapkan TPACK antara lain: 1) Jumlah guru yang memenuhi syarat dalam jumlah kualifikasi (S1), 2) Ruang kelas yang cukup, ruang penunjang lainnya yang dimiliki seperti laboratorium komputer, ruang media, perpustakaan dan ruang ketrampilan, 3) disetiap ruang kelas terdapat fasilitas seperti LCD, serta 4) Fasilitas internet yang digunakan dalam proses pembelajaran. Selama ini di SMA Kristen Satya Wacana belum pernah dilakukan evaluasi kinerja mengajar guru dalam mengimplementasikan TPACK. Dalam hal ini maka perlu diadakan penelitian yang mampu mengungkapan dan atau menilai tentang bagaimana sebetulnya kinerja mengajar guru dalam mengimplementasikan TPACK itu sendiri. Mulyasa (2013) menambahkan juga bahwa evaluasi atau penilaian kerja adalah suatu upaya untuk memperoleh gambaran tentang pengetahuan, ketrampilan, nilai dan sikap seseorang dalam melaksanakan tugas dan fungsinya.

Mishra dan Koehler dalam Sutrisno (2012:101) mengatakan bahwa TPACK adalah kerangka kerja bagi guru dalam memadukan teknologi dalam pembelajaran. Konsep TPACK dalam pembelajaran didasarkan pada Pedagogy content knowledge (PCK). Komponen TPACK terdiri dari: Content Knowledge (CK) (Pengetahuan atau materi), Pedagogical Knowledge (PK) (Pengetahuan Mengajar), Technological Knowledge (TK) (Pengetahuan teknologi), Pedagogical Content Knowledge (PCK) (Pengetahuan mengajar materi), Technological Content Knowledge (TCK) (Pengetahuan mengajar teknologi) dan Technological Pedagogical and Content Knowledge (TPACK) (Pedagogik, konten, dan teknologi). Baran dan Thompson (2011) TPACK menjadi alat dan cara yang efektif untuk meningkatkan kemampuan guru dalam hal penguasaan teknologi dan kemampuan guru dalam menggunakan teknologi dalam proses pembelajaran. Dari hasil penelitian tersebut dapat kita ketahui bahwa TPACK dapat meningkatkan kualitas guru maupun dalam hal penguasaan konten, pedagogik dan teknologi.

Wirawan (2015: 274) Kinerja mengajar Guru adalah suatu prestasi yang diperlihatkan oleh guru dalam menyampaikan materi yang didalamnya meliputi: Sikap, Pengetahuan dan ketrampilan yang diberikan kepada peserta didik karena guru mempunyai kemampuan dalam melaksanakan pembelajaran, dan mengevaluasi dalam suasana interaksi edukasi di sekolah. Pandangan ini sejalan dengan Nasution (2012: 184) yang mengemukakan bahwa kinerja mengajar guru adalah suatu usaha pendidik dalam mengelola perhatian dan waktu siswa yang dilakukan dari awal sampai akhir di dalam kelas atau menciptakan kondisi, megatur lingkungan kelas sedemikian sehingga terjadinya interaksi dengan siswa, guru dan media pengajaran. Indikator kinerja mengajar guru dalam implementasi TPACK dapat dilihat dari tiga aspek kegiatan pembelajaran di kelas yaitu: a) Perencanaan Kegiatan Pembelajaran, dituangkan dalam Rencana Pelaksanaan Pembelajaran (RPP) yang memuat tentang: tujuan pembelajaran, materi pelajaran, kegiatan pembelajaran, pendekatan pengajaran, bahan ajar, teknologi. b) Pelaksanaan Pembelajaran: Menurut Uno dan Lamatenggo (2012:70) menyatakan bahwa pelaksanaan pembelajaran merupakan suatu kegiatan dimana adanya interaksi antara guru dan siswa. Dalam pelaksanaan terdiri atas tiga bagian yaitu: Kegiatan Pendahuluan, inti pembelajaran, dan penutup. c) Evaluasi: Dalam tahap ini guru merencanakan pendekatan dan cara-cara evaluasi, penyusuan alat evaluasi/penilaian, pengolahan, dan penggunaan hasil evaluasi.

\section{METODE}

Jenis penelitian ini ialah penelitian evaluatif. Dalam Penelitian ini digunakan metode penelitian Deskriptif Kuantitatif dan kualitatif. Tujuan Penelitian ini untuk mendapatkan gambaran dan informasi yang selengkap mungkin mengenai kinerja mengajar Guru IPS dalam mengimplementasikan TPACK di SMA Kristen satya Wacana. Subyek dalam penelitian ini adalah, Guru-guru yang tergabung dalam kelompok peminatan IImu Pengetahuan Sosial (IPS). Teknik pengumpulan data dengan cara: Observasi, Wawancara, Dokumentasi, dan Kuesioner. Instrumen yang instrumen yang digunakan diadaptasi dari Denise A. Schmidt, dkk. Kemudian instrumen tersebut di validitas logis oleh dua orang dosen dengan tujuan menilai format instrumen dan kesesuaian itemitem dalam instrumen dengan tujuan pengukuran. Dalam penelitian ini, setiap lembar instrumen (Observasi RPP, Observasi pelaksanaan dan kuesioner) yang digunakan telah memenuhi syarat validitas. Gambaran indikator dalam penelitian ini, dapat disajikan sebagai berikut. 
Tabel 1. Indikator Penilaian Perencanaan, Pelaksanaan, dan Evaluasi Pembelajaran

\begin{tabular}{cl}
\hline Komponen TPACK & \multicolumn{1}{c}{ Indikator } \\
\hline CK & $\begin{array}{l}\text { Keluasan, kedalaman, kesesuain materi } \\
\text { Pegelolaan kelas, Motivasi dan apersepsi, Penyampaian kompetensi } \\
\text { dan rencana kegiatann, Penerapan strategi pembelajaran, } \\
\text { Penggunaan sumber belajar Evaluasi, Refleksi. } \\
\text { Ketrampilan penggunaan teknologi, dan keterlibatan siswa } \\
\text { TK }\end{array}$ \\
PCK & $\begin{array}{l}\text { Kesesuaian tujuan, dengan metode dan bahan ajar. } \\
\text { Integarsi teknologi, penambahan informasi baru dan keterlibatan } \\
\text { Siswa. }\end{array}$ \\
TCK & $\begin{array}{l}\text { Integrasi teknologi dengan pendekatan dan metode. } \\
\text { Integrasi teknologi, konten dan Pendekatan. }\end{array}$ \\
TPACK &
\end{tabular}

Untuk analisis data kualitatif mengacu pada model Miles dan Huberman. Untuk data kuantitatif, dianalis secara deskriptif dan dipersentasekan melalui interpretasi dan dikategorikan (Arikunto:2011).

\section{HASIL DAN PEMBAHASAN}

Berkaitan dengan hasil penelitian ini, dipaparkan berdasarkan hasil analisis data pada aspek perencanaan pembelajaran, pelaksanaan pembelajaran, evaluasi proses dan hasil pembelajaran.
A. Kinerja Mengajar Guru IPS dalam Mengimplementasikan TPACK dari Aspek Perencanaan Pembelajaran

Kinerja mengajar guru IPS dalam mengimplementasikan TPACK dari aspek perencanaan didapatkan dari hasil analisis RPP yang telah dibuat oleh guru kemudian dinilai komponen TPACK meliputi CK, PK, TK, PCK, TCK, TPK, dan TPACK. Berikut ini data hasil analisis RPP guru dalam mengimplementasikan TPACK di SMA Kristen Satya Wacana:

Tabel 2. Kinerja Mengajar Guru IPS dari Aspek Perencanaan Pembelajaran

\begin{tabular}{ccc}
\hline Komponen TPACK & Persentase (\%) & Kategori \\
\hline CK & 89.28 & Baik Sekali \\
PK & 97.44 & Baik Sekali \\
TK & 84.52 & Baik \\
PCK & 85.71 & Baik \\
TCK & 82.14 & Baik \\
TPK & 76.78 & Baik \\
TPACK & 76.78 & Baik \\
\hline Rata-Rata & $\mathbf{8 4 . 6 6}$ & Baik
\end{tabular}

Berdasarkan Tabel tersebut, nilai ratarata yang diperoleh secara keseluruhan (mencakup tujuh komponen) dalam aspek perencanaan pembelajaran berada pada kriteria Baik dengan persentase sebesar 84.66, berada pada komponen PK sebeser 97.44 dengan kategori sangat baik, dan CK sebesar 89.28 dengan kategori sangat baik. Untuk komponen TK, PCK, TCK, TPK, dan TPACK, berada dalam kategori baik. Dalam hal ini setiap guru sudah membuat dan mengembangkan RPP yang memuat seluruh komponen TPACK, serta dalam RPP tersebut sudah memilih metode pembelajaran yang disesuikan dengan $\mathrm{KI}$ dan $\mathrm{KD}$, penggunaan metode yang bervariatif, pengembangan materi dari berbagai sumber seperti LKS, buku paket, modul. Dan juga dalam RPP sudah mencantumkan penggunaan teknologi seperti perangkat LCD, Laptop, Slide power point, video, dengan tujuan untuk membantu siswa dalam memahami setiap materi yang akan diajarkan.

Secara keselurahan kinerja mengajar guru IPS dalam mengimplementasikan TPACK dalam aspek perencanaan pembelajaran dapat dilihat kemampuan guru dalam menerapkan komponen-komponen TPACK. Dalam komponen CK ini guru sudah menjabarkan materi yang sesuai dengan kompetensi inti dan kompotensi dasar yang terdapat pada RPP serta guru sudah bisa mengembangkan setiap materi dan juga memberikan informasi baru terkait materi yang diajarkan yang diambil dari berbagi sumber, seperti buku paket, sumber internet, modul, LKS dan buku penunjang lainnya. Kedalaman materi dalam hal ini guru sudah 
mencantumkan setiap materi yang terdapat pada RPP secara detail. Hal ini sejalan dengan pernyataan Abdur dalam Endang, dkk (2018:8) yaitu bahwa setiap guru tidak hanya memiliki pemahaman yang mendalam pada materi tertentu, tetapi guru juga dapat memiliki pengetahuan yang luas. Ini berati bahwa guru harus mampu dalam membangun setiap konsep materi yang diajarkan. Dalam RPP yang telah dibuat oleh guru menunjukkan juga adanya kesesuaian antara materi dengan KD, tujuan dan indikator dan dari hasil wawancara juga menunjukkan bahwa setiap guru membuat RPP, sehingga dapat menyesuaikan antara materi dan $\mathrm{KD}$.

Dalam komponen PK pengetahuan akan strategi pembelajaran sudah dicantumkan yaitu pendekatan saintific dalam RPP. Hal ini menjelaskan bahwa pengetahuan setiap guru mengenai berbagai pendekatan sangat dibutuhkan. Dalam penggunaan metode dan model juga guru sudah mencantumkan metode yang digunakan pada RPP yaitu metode, diskusi, tanya jawab, bermain peran, dan modelnya yaitu PBL, STAD, discovery learning, inquiry sesuai dengan tuntutan kurikulum 2013.

Pada pengetahuan akan media guru telah mencantumkan media pembelajaran yang digunakan baik bersifat elektronik atau konvensional, seperti menggunakan video, power point, gambar, buku paket dan LKS. Menurut Endang, dkk (2018:8), menyatakan bahwa penggunaan media sangat diperlukan bagi seorang guru agar dapat mewujudkan pembelajaran yang efektif serta dapat menunjang pemahaman siswa terhadap materi yang diajarkan. Pada indikator evaluasi dari hasil analisis RPP, telah menunjukkan bahwa setiap guru telah mencantumkan penilaian yang didalamnnya terdapat penilaian kognitif (melampirkan soal-soal pilihan ganda dan essay), afektif (jurnal kelas) dan psikomotorik (lembar observasi kinerja). Hal ini sejalan dengan pendapat Endang, dkk (2018:9), yang menyatakan bahwa penilaian sebagai suatu komponen penting dalam proses pembelajaran sehingga dapat digunakan sebagai tolak ukur dari pemahaman siswa.

Pada komponen TK dari hasil analisis RPP menunjukkan bahwa guru sudah mampu mengambarkan tentang penggunaan teknologi dan kemampuan guru dalam menggunakan teknologi tersebut. Dalam hal ini setiap guru sudah memaparkan setiap materi dalam bentuk PPT, penggunaan sofware atau aplikasi pembelajaran. Menurut Daryanto (2017:2) menjelaskan bahwa penggunaan teknologi dalam pembelajaran memiliki pengaruh yang penting terhadap pemahaman siswa. Dan bila dikaitkan dengan ketrampilan abad 21 yang ditandai dengan tuntutan seorang guru harus bisa menguasai dan memanfaatkan teknologi informasi dan komunikasi dalam segala aspek kehidupan, khususnya dalam bidang pendidikan.

Komponen PCK yang merupakan pemahaman guru tentang pendekatan dan metode pembelajaran yang efektif untuk menyampaikan materi pelajaran. Hasil observasi menunjukkan bahwa guru membuat RPP sehingga ketika melaksanakan pembelajaran guru sudah dapat menyesuaikan antara pendekatan dan metode yang digunakan. Menurut Etkina (2010) menyatakan bahhwa PCK adalah gabungan dari pengetahuan konten dan pedagogik dalam hal pemahaman akan topik bahasan dan materi yang terorganisir yang kemudian dibantu dengan pengintegrasian pendekatan dan metode pembelajaran dengan konten dalam pembelajaran. Baumert, dkk (2010:164) menjelaskan bahwa dengan adanya kemampuan PCK serta guru menguasainya, maka kan memberikan manfaat bagi siswa yang memiliki prestasi yang rendah.

Komponen TCK Dalam RPP, guru sudah mampu mencamtumkan materi berbasis teknologi atau integrasi teknologi dalam materi, seperti penayangan video, gambargambar dengan power point dan memanfaatkan fasilitas internet. Bila dikaitkan dengan perkembangan teknologi pada abad ke 21 ini yang menjadi bahan perhatian bagi guru agar selalu mengembangkan kemampuan mengajarnya (Daryanto 2016:4).

Komponen TPK dalam RPP guru sudah mencantumkan media pembelajaran berbasis teknologi. Menurut Daryanto (2016: 16) menyatakan bahwa keuntungan bagi guru dalam penggunaan komputer akan mempermudah dan mempercepat kerja siswa dan juga bisa menimbulkan rasa senang pada siswa karena siswa bisa melihat gambar, mendengarkan suara (audio), melihat video dengan cara instan. Dapat dikatakan bahwa situasi ini bisa menjadi suatu faktor pendukung atau sangat penting untuk mencapai efektivitas belajar.

Komponen TPACK yang merupakan puncak dari pengetahuan sehingga dapat dikatakan sebagai pengetahuan yang sangat baik bagi seorang guru, karena TPACK memuat tiga unsur utama yaitu pengetahuan teknologi, Pedagogik, Konten. Dari hasil analisis RPP menunjukkan bahwa guru sudah mencantumkan materi, model, metode, media pembelajaran dengan materi. Nofrian dkk 
tahun 2012, TPACK sangat diperlukan dalam pembelajaran IPS karena TPACK Merupakan dasar mengajar yang efektif dengan teknologi yang memerlukan pemahaman tentang representasi dari materi/konten yang sulit atau mudah. Tujuannya adalah agar mempermudah guru dalam membantu dan memperbaiki beberapa masalah yang dihadapi siswa, yaitu pengetahuan siswa dan pengetahuan tentang teknologi, serta dapat digunakan untuk membangun pengetahuan dan mengembangkan metode/cara-cara baru.

\section{B. Kinerja Mengajar Guru IPS dalam Mengimplementasikan TPACK dari Aspek Pelaksanaan Pembelajaran \\ Pada tahap pelaksanaan, peneliti} mengamati guru dalam melaksanakan pembelajaran dengan menggunakan lembar instrumen yang telah disiapkan. Kinerja mengajar guru yang diukur adalah komponen CK, PK, TK, PCK, TCK, TPK, dan TPACK. Kinerja mengajar guru dalam mengimplementasikan TPACK dalam aspek pelaksanaan pembelajaran ini dianalisis seacara deskriptif.

Tabel 3. Kinerja Mengajar Guru IPS dari Aspek Pelaksanaan Pembelajaran

\begin{tabular}{ccc}
\hline Komponen TPACK & Persentase $(\%)$ & Kategori \\
\hline CK & 89.28 & Baik Sekali \\
PK & 97.44 & Baik Sekali \\
TK & 84.52 & Baik \\
PCK & 85.71 & Baik \\
TCK & 82.14 & Baik \\
TPK & 76.78 & Baik \\
TPACK & 76.78 & Baik \\
\hline Rata-Rata & $\mathbf{8 4 . 6 6}$ & Baik \\
\hline
\end{tabular}

Dari Tabel tersebut kinerja mengajar guru dalam mengimplementasikan TPACK, yang dilihat dari aspek pelaksanaan pembelajaran menunjukkan bahwa kinerja mengajar guru ada pada ketegori baik dengan rata-rata persentase sebesar 81.25. Pada komponen CK berada pada kategori Baik sekali dengan tingkat persentase sebesar 98.80. Sedangkan komponen PK, TK, PCK, TCK, TPK, dan TPACK berada pada kategori baik. Hasil observasi menunjukan bahwa guru sudah menyanjikan materi secara sistematis dengan berbantuan teknologi, seperti PPT, Audio, Video dan beberapa sofware lainya. Implementasi TPACK secara real, sudah dilakukan oleh guru didalam kelas, dengan adanya penggunaan model, metode, dan adanya dukungan dari pihak sekolah dalam membantu guru dalam mengintegrasikan TPACK.

Kinerja mengajar guru IPS dalam mengimplementasikan TPACK dilihat dari aspek perencanaan dapat dijelasakan melalui tujuh komponen yaitu: Komponen CK dari hasil observasi langsung saat guru melaksanakan pembelajaran, memperlihatkan bahwa setiap guru sudah menyampaikan materi sesuai KD, metode, sesuai dengan yang dicantumkan dalam RPP serta dapat menganalogikan materi dengan contoh-contoh yang ada pada kehidupan sehari-hari. Komponen PK dari hasil observasi guru sudah menyesuaikan antara metode yang dicantumkan pada RPP, dalam menyajikan materi pelajaran sudah menunjukkan kemampuannya dalam hal penguasaan bahan belajar, sehingga materi sudah disampaikan secara sistematis dan jelas, karena bahan belajar yang disajikan sesuai dengan langkah-langkah dalam RPP. Purwoko (2017:64) mengungkapkan dengan adanya penguasaan $\mathrm{CK}$ yang baik, serta dimiliki oleh guru, akan sangat penting ketika guru memberikan pemahaman yang utuh bagi siswa dalam menjelaskan setiap materi. Kinerja mengajar guru dalam menggunakan media/alat telah menunjukkan kemampuannya dengan baik serta dalam menyajikan setiap materi guru sudah mampu menggunakan media dan alat peraga yang dapat membantu guru dalam pelaksanaan pembelajaran dengan efektif. Pemilihan metode yang baik disesuikan dengan karakteristik siswa. Menurut Daryanto (2016:37) menjelaskan bahwa metode pengajaran adalah suatu cara yang digunakan oleh guru dalam menjalankan funsginya serta metode merupakan alat untuk dapat mencapai setiap tujuan pembelajaran.

Komponen TK dari hasil observasi guru telah menunjukkan kemampuannya dalam menggunakan teknologi baik dalam bentuk sofware dan hadware. Kemampuan guru tersebut dapat dilihat ketika guru melaksanakan pembelajaran, guru sudah menggunakan alat-alat elektornik modern sebagai media pembelajaran. Yang biasa digunakan oleh guru yaitu laptop, proyektor. 
Setiap guru sudah menggunakan power point dalam menyampaikan materi, serta dalam power point juga, guru sudah mampu menyisipkan video-video yang berkaitan dengan materi. Selain itu guru sudah mampu menggunakan program pengolah kata dan gambar, hal ini dapat dilihat ketika guru menyajikan materi dalam proses pembelajaran. Tezci (2010:35) mengatakan dengan adanya penguasaan TK yang dimiliki oleh guru akan sangat membantu guru dalam menjelaskan materi yang ada, serta dapat mencapai tujuan pembelajaran yang dicapai, dan juga dapat meningkatkan minat siswa dalam mempelajari materi.

Komponen PCK dari hasil pengamatan dalam proses pembelajaran ini dapat terlihat bahwa guru sudah mampu: (a) menyesuaikan materi dengan pendekatan, model, dan metode pembelajaran, (b) menyesuaikan materi dengan media pembelajaran dan (c) adanya interaksi antar guru dan siswa yang terlihat selama proses pembelajaran. Bertram (2012:3) menjelaskan bahwa interaksi yang luas antara pengetahuan konten, guru dan siswa dalam proses pembelajaran sangat tergantung pada kemampuan yang dimiliki oleh guru sendiri. Agustina (2015:3) menjelaskan bahwa seorang guru tidak hanya menguasai materi dan konsep saja, tetapi juga harus menguasai setiap cara dalam mengajarkan materi dan strategi yang akan diajarkan kepada siswa. Untuk itu juga guru dituntut untuk bisa memanfaatka teknologi dalam mengajar. Komponen TCK Hasil observasi menunjukkan bahwa guru sudah menggunakan teknologi yang disesuaikan dengan bahan ajar. Dalam menyampaikan materi, guru sudah memberikan informasi-informasi baru terkait dengan materi pada siswa, dengan memanfaatkan fasilitas teknologi (internet). Menurut Mairisiska (2014:29) menjelaskan bahwa pentingnya penggunaan teknologi untuk mendukung tercapainya tujuan pembelajaran yang disampaikan. Dengan pemanfaatan teknologi akan membuat materi yang abstrak menjadi lebih muda dipelejari oleh siswa.

Komponen TPK Berdasarkan hasil observasi telah menunjukkan bahwa guru sudah menggunakan media pembelajaran yang berbasis TIK, seperti penggunaan Power point, penggunaan aplikasi pembelajaran. Menurut Mairisiska (2014:30) menyatakan bahwa saat ini TIK sangat penting dalam proses belajar dan mengajar, siswa dapat mengakses berbagai informasi, video, gambar, melalui gadget elektronik, dan guru dapat menggunakan gambar, artikel, dan video dengan memanfaatkan teknologi. Dapat dikatakan bahwa keberhasilan implementasi TIK dalam proses pembelajaran akan sangat tergantung pada ketrampilan, kemampuan, dan kreatifitas guru dalam memanfaatkan TIK.

Komponen TPACK Berdasarkan hasil observasi dalam pembelajaran guru sudah mampu menyesuaikan antara pendekatan, media, materi, serta menggunakan teknologi dengan baik. Hal tersebut dapat dilihat dari adanya dukungan fasilitas dari pihak sekolah, sehingga dapat menunjang proses pembelajaran yang efektif. TPACK menjadi suatu sentral dalam mencapai setiap tujuan pembelajaran. Apabila TPACK diterapkan dengan baik, maka siswa akan mendapatkan pembelajaran yang lebih bermakna. Pentingya penerapan TPACK seperti yang dikatakan oleh Putriani (2015:25), yang menyatakan bahwa TPACK dapat meningkatkan penguasaan konsep/materi dan keaktifan belajar siswa.

\section{Kinerja Mengajar Guru IPS dalam Mengimplementasikan TPACK dari Aspek Evaluasi Pembelajaran}

Evaluasi pembelajaran dilakukan oleh guru dengan tujuan dapat mengetahui apakah tujuan pembelajaran sudah tercapai atau belum, sehingga dapat digunakan sebagai bahan pertimbangan perbaikan bagi guru dan siswa. Dalam tahap ini komponen TPACK yang dievaluasi adalah komponen PK.

Tabel 4. Kinerja Mengajar Guru IPS dalam Penilaian/Evaluasi Pembelajaran

\begin{tabular}{ccc}
\hline Komponen TPACK & Persentase (\%) & Kategori \\
\hline PK & 85.78 & Baik \\
\hline Rata-Rata & $\mathbf{8 5 . 7 8}$ & Baik \\
\hline
\end{tabular}

Dari Tabel tersebut menunjukkan bahwa kinerja mengajar guru dalam penilaian/evaluasi pembelajaran berada pada kategori baik dengan persentase sebesar 85.78. Pada tahap evaluasi setiap guru melakukan refleksi diri dengan cara mempertimbangkan materi yang sudah disampaikan dan dalam melakukan evaluasi, setiap guru melakukan penilaian dengan cara penilaian evaluasi proses pembelajaran dan evaluasi akhir pembelajaran. Dalam melakukan penilaian/evaluasi setiap guru 
sudah melakukan evaluasi yang sesui dengan Pedagogical Knowledge (PK).

Berdasarkan hasil observasi kinerja mengajar guru IPS dalam mengimplementasikan TPACK dari aspek evaluasi pembelajaran yang dilihat dari komponen PK. Dalam pemilihan rana penilaian evaluasi sudah dikategorikan dengan baik, bahwa guru telah membuat dan melakukan penilaian terhadap siswa, ketika melaksanakan pembelajaran serta guru mampu menggunakan berbagai macam ranah evaluasi. Dalam hal ini ranah evaluasi yang dimaksud adalah penilaian kognitif, penilain afektif, dan penilain psikomotirik. Penilaian kognitif yang sering dilakukan guru yaitu dengan adanya soal-soal pilihan ganda maupun uraian. Untuk penilaian afektif dilakukan dengan cara menggunakan jurnal kelas, yang memuat tentang catatan, hasil temuan guru, ketika melaksanakan pembelajaran. Dalam hal pemilihan dan juga penggunaan ketiga ranah tersebut guru sudah mampu melaksanakan penilain ketika guru tersebut melaksanakan pembelajaran di dalam kelas. Dan yang sering digunakan oleh guru adalah penilaian afektif dan kognitif.

Dalam pemilihan alat evaluasi guru telah mampu menyusun rubrik penilaian kognitif, afektif, dan psikomotorik dengan baik, serta mampu mengembangkan instrumen penilaian dengan baik juga. Bentuk penilaian yang biasa dilakukan adalah pada akhir pelajaran adalah dalam bentuk tes tulis. Dalam pembuatan soal yang dilakukan oleh guru, setiap soal juga sudah mengarah pada soal-soal HOTS, serta guru sudah mampu menyusun kisi-kisi sebelum membuat soal untuk tes. Menurut pendapat Eko (2014:23) menyatakan bahwa kisi-kisi adalah suatu format yang memuat tentang kriteria soal-soal yang berisi tentang deskripsi kompetensi dan materi yang diwujudkan dalam sebuah Tabel yang memuat perincian materi serta imbangan atau proporsi yang dikendaki oleh penilai.

\section{PENUTUP}

Berdasarkan hasil analisis penelitian dan pembahasan, dapat disimpulkan sebagai berikut: (1) Kinerja Mengajar guru IPS dalam mengimplementasikan TPACK dari aspek perencanaan pembelajaran, menunjukkan bahwa kinerja mengajar guru berada pada kategori baik dengan persentase sebesar 84.66\%. Untuk komponen CK dan PK kategori baik sekali, TK, PCK, TCK, TPK, dan TPACK, berada pada kategori Baik. Pada aspek ini, setiap guru sudah membuat RPP dan mencantumkan setiap komponen TPACK dalam RPP, baik penggunaan metode, model, strategi, teknologi dan tetap memperhatikan isi konten atau materi yang dicantumkan. (2) Kinerja mengajar Guru IPS dalam mengimplementasikan TPACK dari aspek pelaksanaan pembelajaran, menunjukkan bahwa kinerja mengajar guru berada pada kategori baik dengan persentase sebesar 81.25\%. Untuk komponen CK berada pada kategori Baik sekali, PK, TK, PCK, TCK, TPK, dan TPACK berada pada kategori baik. Dalam hal ini setiap guru sudah menjelasakan materi secara sistematis dengan berbantuan teknologi, pengelolaan kelas baik, ketrampilan menggunakan teknologi, kesesuain antara metode, model dan konten di implementasikan secara real didalam kelas. (3) Kinerja mengajar Guru IPS dalam Mengimple $\neg$ mentasikan TPACK dari aspek evaluasi pembelajaran, menunjukkan bahwa kinerja mengajar guru berada pada kategori baik dengan persentase sebesar $85.78 \%$. Dalam hal ini setiap guru sudah melakukan refleksi dan juga mengembangkan setiap instrumen penilaian baik penilaian kognitif, afektif, dan psikomotorik, pemilihan alat evaluasi, kesesuaian dan perbaikan penilaian.

Berdasarkan kesimpulan yang telah diperoleh dari penelitian, saran yang dapat disampaikan dari peneliti ini adalah (1) Agar kinerja mengajar guru makin meningkat, diharapkan setiap guru dapat mengembangkan kemampuan TPACK guru dari aspek pelaksanaan pembelajaran yaitu dalam komponen TCK dan TPK. (2) Untuk peneliti selanjutnya diharapkan dapat melaksanakan penelitian yang cakupannya lebih luas untuk seluruh guru mata pelajaran dan saat melakukan observasi minimal dilakukan tiga kali sehingga dapat diketahui secara mendalam tentang kinerja mengajar guru dalam suatu lembaga pendidikan.

\section{DAFTAR PUSTAKA}

Agustina, P. (2015). Pengembangan PCK (Pedagogical Content Knowledge) Mahasiswa Calon Guru Biologi FKIP Universitas Muhammadiyah Surakarta Melalui Simulasi Pembelajaran." Jurnal Penelitian dan Pembelajaran IPA, 1(1), 9-11.

Arikunto, S. (2011). Manajemen Penelitian. Jakarta: Rineka Cipta 
Baran, E., \& Thomson, A. (2011). TPACK An Emerging Research And Development Tool For Teacher Educators. TOJEFT: The Turkish Online Journal of Educational Technology.

Baumert, Kunter, M., Blum, W, Brunner, M. Voss, T., Jordan, A., \& Tsai, Y. M. (2010). Teachers' mathematical knowledge, cognitive activation in the classroom, and student progress. American educational research journal, $\quad 47(1), \quad$ 133-180. https://doi.org/10.3102/000283120934 5157

Bertram, A., \& Loughran, J. (2012). Science Teachers' Views on CoRes and PaPeRs as a Framework for Articulating and Developing Pedagogical Content Knowledge. Research Science Education. 42:1027-1047 DOl $10.1007 / \mathrm{s} 11165-011-9227-4$

Daryanto. (2017). Pendekatan Pembelajaran Saitifik Kurikulum 2013. Gave Media: Yogyakart

Daryanto. Karim, Syaiful. (2017). Pembelajaran Abad 21. Gave Media: Yogyakarta.

Denise, et al (2009). Technological Pedagogical Content Knowledge (TPACK): The Development and Validation of an Assessment Instrument for Preservice Teachers. Journal of Research on Technology in Education.

Eko, Widoyoko, P. (2014). Penilaian Hasil Pembelajaran di Sekolah. Edisi Revisi. Pustaka Pelajar : Yogyakarta.

Endang, S. dkk. (2018). Kemampuan Technological Pedagogical and Content Knowledge (TPACK) Guru IPA di Sekolah Inklusi SMP Negeri 23 Surakarta Tahun Ajaran 2017 - 2018 http://eprints.ums.ac.id/62434/

Etkina, E. (2010). Pedagogical Content Knowledge and Preparation of High School Physics.

Ibnu, Rafi. Dan Sabrita, Nurrita (2018). Pengintegrasian TPACK dalam
Pembelajaran Transformasi Geometri SMA unutk megembangkan profesionalitas Guru Matematika. Supremun Journal Of Mathematics Education (SJME) . Vol.3, No. 1. ISSN: 2548-8163 (online)| ISSN: 25493639.

Marzano, R J \& Heflebower, T. (2012). Teaching \& Asssing 21st Century skills (The Classroom strategies series). EBook From marzanoreserch.com

Mairisiska,T.,Sutrisno.,Asrial.(2014).

Pengembangan Perangkat Pembelajaran Berbasis TPACK pada Materi Sifat Koligatif Larutan untuk Meningkatkan Keterampilan Berpikir Kritis Siswa. Jurnal Pendidikan Matematika dan IImu Pengetahuan Alam, 3(1) 28-37.

Muhsin, Nur \& Sutommo, Y. 2016. Pengaruh Kepribadian dan Motivasi Kerja Terhadap Kinerja Guru Dimoderasi Budaya Organisasi Pada Madrsah Tsana Wiyah Swasta Kecamatan Winong Kabupaten Pati.http://www.unisbank.ac.id/ojs/inde x.php/pasca1/article/view/4695

Mulyasa, E. 2013. Uji Kompetensi dan Penilain Kinerja Guru. Bandung: PT Remaja Rosdakarya

Nasution, S. (2012). Berbagai Pendekatan dalam Proses Belajar \& Mengajar. Jakarta: Bumi Aksara.

Nofrion., Wijayanto, Bayu., Wilis, Ratna., \& Novio, Rery., (2017). Analisis Technological Pedagogical And Content Knowledgge (TPACK) Guru Geografi. Jurnal Geografi. At

https://jurnal.unimed.ac.id/2012/index.php/geo/ article/view/9070/9430

Peraturan Mentri Pendidikan dan Kebudayaan Republik Indonesia nomor 22 tahun 2016 tentang Standar Proses pendidkan Dasar dan Menengah. (Diakases 29 Juli 2019).

Purwoko, R. Y. (2017). Analisis Kemampuan Content Knowledge Mahasiswa Calon Guru Matematika pada Praktek Pembelajaran Mikro. Jurnal 
Pendidikan Surya Edukasi (JPSE), $3(1), 55-65$.

Putriani, \& Sarwi, (2015). Impelementasi Strategi TPACK Dengan Media Simulasi Berbasis Inkuri Terbimbing Pada Konsep Getaran Dan Gelombang. Journal Unnes Physics Eduation.

http://journal.unnes.ac.id/sju/index.php /upej.

Suryyawati, Evi., Hernandez, Yosua. 2014. Analisis ketrampilan Technological Pedagogical Content Knowledge (TPCK) Guru Biologi SMA Negeri Kota Pekanbaru. Jurnal Biogenesis. Vol. 11. Pekanbaru. Dapat di akses melalui https://ejournal.unri.ac.id/index.php/JP SB/article/view/2478

Tezci, E. (2010) Attidues and Knowledge level of teachers in ICT use. The case of turkish teachers. Journal of human sciences. https://b jhumansciences.com/ojs/index.php/lJ HS/article/view/ 97/570

Undang-undang No.20 Tahun 2003 tentang Sistem Pendidikan Nasional

Undang-undang No.14 Tahun 2005 tentang Guru dan Dosen.

Uno, B, Hamzah. \& Lamatenggo, Nina. 2012, Teori Kinerja dan pengkurannya (Universitas Negeri Malang). Jakarta: Bumi Aksara

Wirawan. 2015, Evaluasi Kinerja Sumber Daya Manusia (Teori, Aplikasi, dan Penelitian. Jakarta: Salemba Empat. 